\title{
Ground water quality evaluation in the lean period of a mining township
}

\author{
Bably Prasad $^{1} \cdot$ Deblina Maiti $^{1} \cdot$ Adarsh Kumar $^{1}$
}

Received: 12 November 2015/Accepted: 18 September 2017/Published online: 23 September 2017

(c) The Author(s) 2017. This article is an open access publication

\begin{abstract}
Groundwater of mining towns is very much affected due to mining activity. During mining of mineral from underground, huge quantity of ground water is pumped out to make mining possible. Groundwater samples have been collected from the 20 sampling sites of Dhanbad, a mining Township, in the lean period (summer) of the years 2011 and 2014. Four samples have been obtained from open well and 16 from hand pumps. Water quality parameters such as $\mathrm{pH}$, total hardness, Ca hardness, Mg Hardness, chloride, sulphate, total dissolved solids, and heavy metals have been evaluated. The values of $\mathrm{pH}$, total hardness, Ca hardness, $\mathrm{Mg}$ hardness, chloride, sulphate, and total dissolved solids have increased in 2014 as compared to 2011 which may be due to increase in mineral content in the lean period and decrease in the rate of recharge of aquifers in 2014. The concentration of heavy metals has decreased in 2014 as compared to 2011 which may be due to less leaching of heavy metals from the ground strata. From the overall study, it has been concluded that most of the water quality parameters of all the 20 groundwater samples in the year 2014 are not exceeding the acceptable concentration level, as mentioned in Indian drinking water specifications. Groundwater in the year 2014 has not shown any significant change in its quality as compared to the year 2011. In the incoming years, quality of groundwater will not show any drastic change unless and until any anthropogenic activity other than mining will affect it.
\end{abstract}

Bably Prasad

drbablyprasad@yahoo.com

1 CSIR-Central Institute of Mining and Fuel Research (CSIRCIMFR), Barwa Road Campus, Dhanbad, India
Keywords Groundwater · Water quality parameters · Coal mining $\cdot$ Heavy metals $\cdot$ Heavy metal pollution index

\section{Introduction}

Groundwater is becoming a major concern with respect to coal mining (Karroum et al. 2017; Kumari et al. 2014). Dhanbad, the coal capital of India, is famous for coal mining. Groundwater of Dhanbad town is very much affected due to nearby mining activity in Jharia coalfields. During mining, a large amount of groundwater is pumped out to make mining possible (Prasad et al. 2014; Selvakumar et al. 2017; Srinivas et al. 2017). This creates problem to groundwater with respect to its quality as well as quantity (Custodio et al. 2016; Saravanakumar and Kumar 2011). Mining affects the physical and chemical changes in the mine environment resulting in groundwater pollution (Pathak and Banerjee 1992; Singh 1988; Verma et al. 2017). Bukowski et al. (2006) have reported that underground mining operations can be associated with many environmental effects like vulnerability of groundwater to pollution and the effects of mining on useful aquifers. Banks et al. (1997) have reviewed the variety of hydro-chemical characteristics, environmental impacts, and treatment methods pertaining to groundwater discharging from mines. Seeing the importance of groundwater quality in mining area, the investigation has been carried out to understand the changes in groundwater quality of Dhanbad township within 3 years of time duration (May 2011-May 2014). Heavy metal pollution index (HPI) of the groundwater has also been evaluated according to described methodology (Prasad and Jaiprakas 1999; Prasad and Bose 2001; Prasad and Kumari 2008; Prasad and Mandal 2008; Prasad et al. 2011; Chabukdhara et al. 2017). On the basis of

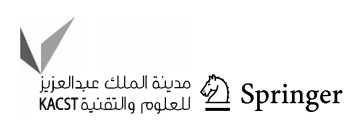


Fig. 1 Layout of Dhanbad township showing different groundwater sampling points

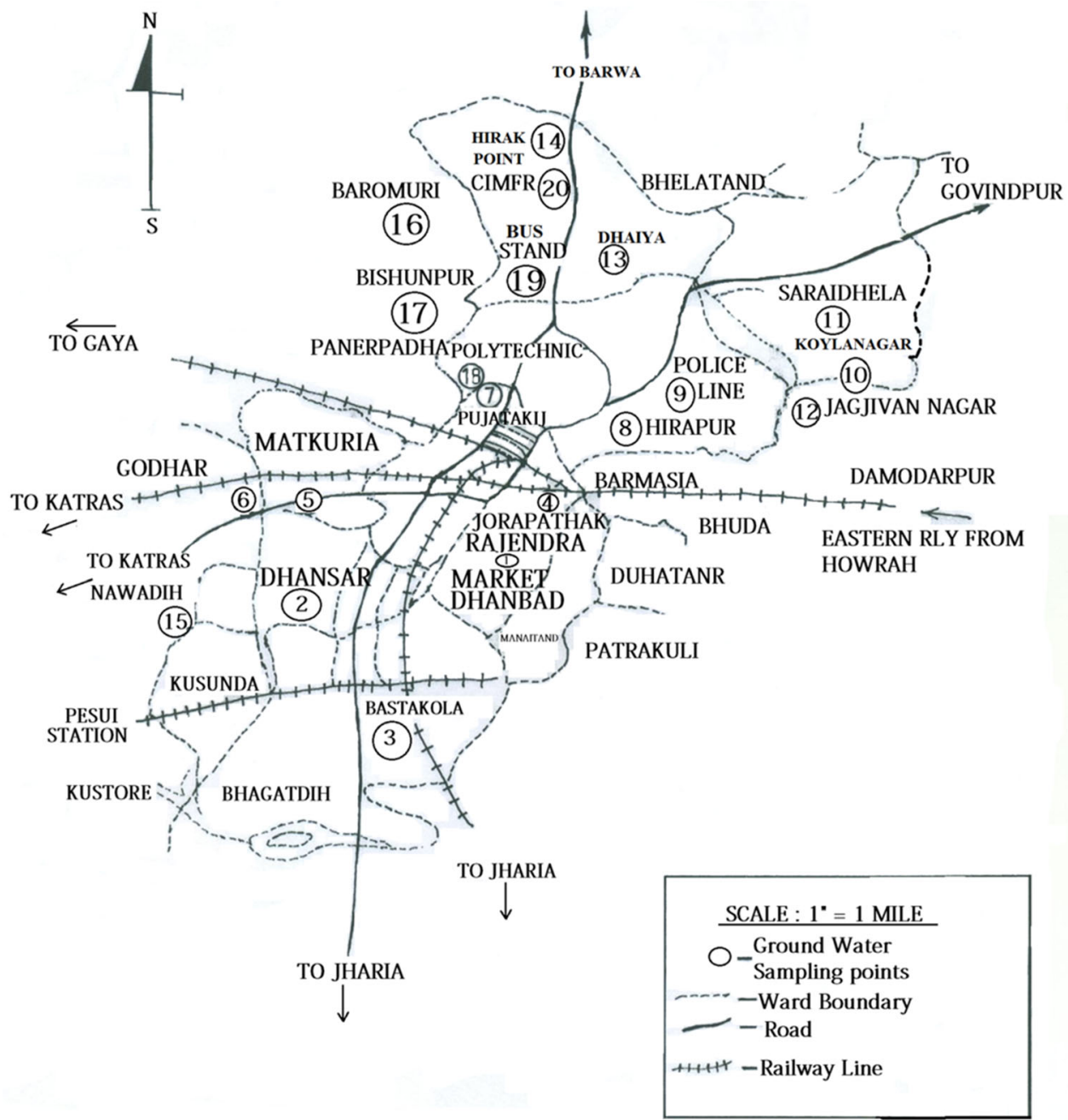

this, groundwater quality of Dhanbad township has been predicted.

\section{Materials and method}

\section{Study area}

Dhanbad, one of the biggest coal belts of India, is actively associated with mining activities for more than a century. The oldest geological formations of the Dhanbad district are composed of crystalline metamorphic rocks which belong to Dharwar system in Indian stratigraphy. In these formations, rock types of both sedimentary and igneous origin are found. Course gritty soil is predominant in Dhanbad coal basin (Gautam et al. 2015). This type of soil mixed with big fragment of rocks is formed from the weathering of pegmatite, quartz, and conglomeratic sandstones. About 200 coal mines of Jharia coal fields, which produce prime coking coal, are located around Dhanbad
Township. The large-scale industries such as coal washing and coke making are located nearby. There is drinking water shortage in the township, especially in summer season. The population here is mainly depended on ground water sources. Taking all these into consideration, 20 groundwater sampling points have been selected, which covered almost entire township of Dhanbad (Fig. 1). Study of quality of selected groundwater samples had been carried out in the lean period of the years 2011 and 2014 to know the changes if any due to mining and allied activities.

\section{Sampling and analysis}

Out of 20, four samples have been taken from open well and 16 from hand pumps. The depth of open wells has been 25-30 feet and hand pumps 100-120 feet. Sampling has been done for the month of May (Summer) 2011 and May 2014 to get an idea of the change in concentrations of water quality parameters in 3 year time duration. Groundwater 
samples have been collected in 2.51 plastic containers prerinsed with groundwater. Analysis of different water quality parameters such as $\mathrm{pH}$, total hardness, Ca hardness, Mg hardness, sulphate, chloride, and TDS has been carried out according to the standard method (IS: 3025 2009). For analysis of heavy metals, samples have been digested, concentrated, and prepared for analysis by Atomic Absorption Spectrophotometer (AAS) Model: M Series Thermo Fisher (Arnold et al. 1992). The digestion and concentration of water sample were carried out by reducing the volume of $1000-50 \mathrm{ml}$ by slow heating on a hot plate with the addition of few milliliters of concentrated nitric acid. Slow heating was done to avoid metal loss due to evaporation. Analysis of metals has been performed by calibrating the instrument with different dilutions of the standard solutions and analysis of $\mathrm{Cu}, \mathrm{Mn}, \mathrm{Pb}, \mathrm{Fe}, \mathrm{Cd}, \mathrm{Zn}$, and $\mathrm{Cr}$ was performed at 324.7, 279.5, 217.0, 248.3, 228.8, 213.9, and $357.9 \mathrm{~nm}$, respectively. Three replicates were run for each sample and the instrument was recalibrated after analysis of ten samples. The detection limit of AAS was well within the range for all elements analyzed. Overall precision expressed as percent relative standard deviation was obtained for all the samples. Because the samples were concentrated during digestion, the result obtained was calculated to get the actual concentration value.

\section{Results and discussion}

The results of physico-chemical analysis of 20 groundwater samples of Dhanbad Township, in lean period (summer) are given in Table 1. From Table 1, it has been observed that the highest $\mathrm{pH}$ value of 7.68 and the lowest of 5.82 in the year 2011, whereas the highest $\mathrm{pH}$ of 7.15 and the lowest of 5.95 in the year 2014 have been obtained. The $\mathrm{pH}$ value has not shown any remarkable change during the 3 years of period. In the year 2011, highest total hardness, $\mathrm{Ca}$ hardness, $\mathrm{Mg}$ hardness, chloride, sulphate, and total dissolved solids have been found 684, 456, 59.3, 260, 379, and $1184 \mathrm{mg} / \mathrm{l}$, respectively. Whereas in the year 2014, these values have been found $860,504,86.51,356,547$, and $1402 \mathrm{mg} / \mathrm{l}$, respectively (Fig. 2). The increased concentrations of the above parameters in 2014 clearly indicate that it may be due to increased mineral content in groundwater in the lean period of 2014 as recharge of aquifers is lesser in 2014 than in 2011. In six groundwater samples in 2011 and 2014, the total hardness value exceeded the desirable limit of $300 \mathrm{mg} / \mathrm{l}$ as per drinking water specification (IS: 10500). Increased concentration of sulphate in 2011 and 2014 has been observed in groundwater sampling point $20(379 \mathrm{mg} / \mathrm{l})$ and $5(547.36 \mathrm{mg} / \mathrm{l})$, respectively. In rest all groundwater samples, sulphate has been found less than $200 \mathrm{mg} / \mathrm{l}$ (desirable limit of drinking

Table 1 Analysis of different parameters of groundwater in lean period of years 2011 and 2014 (in mg/l except pH)

\begin{tabular}{|c|c|c|c|c|c|c|c|c|c|c|c|c|c|c|}
\hline \multirow[t]{2}{*}{ Sampling site } & \multicolumn{2}{|l|}{$\mathrm{pH}$} & \multicolumn{2}{|c|}{ Total hardness } & \multicolumn{2}{|c|}{ Ca hardness } & \multicolumn{2}{|c|}{ Mg hardness } & \multicolumn{2}{|l|}{ Sulphate } & \multicolumn{2}{|c|}{ Chloride } & \multicolumn{2}{|l|}{ TDS } \\
\hline & 2011 & 2014 & 2011 & 2014 & 2011 & 2014 & 2011 & 2014 & 2011 & 2014 & 2011 & 2014 & 2011 & 2014 \\
\hline 1 & 7.17 & 6.78 & 120 & 116 & 76 & 92 & 10.692 & 5.832 & 21.442 & 20.6 & 40 & 76 & 244 & 223.5 \\
\hline 2 & 5.82 & 6.15 & 232 & 240 & 120 & 136 & 27.216 & 25.272 & 92.288 & 100.528 & 68 & 128 & 579 & 313 \\
\hline 3 & 7.29 & 6.93 & 128 & 124 & 92 & 88 & 8.748 & 8.748 & 70.864 & 79.516 & 88 & 148 & 322 & 332.5 \\
\hline 4 & 6.92 & 6.71 & 684 & 496 & 456 & 300 & 55.404 & 47.628 & 181.28 & 94.348 & 220 & 356 & 1184 & 1105.5 \\
\hline 5 & 7.26 & 6.87 & 284 & 860 & 156 & 504 & 31.104 & 86.508 & 56.44 & 547.36 & 68 & 188 & 446 & 1401.5 \\
\hline 6 & 6.53 & 6.17 & 212 & 236 & 120 & 112 & 22.356 & 30.132 & 119.48 & 191.58 & 56 & 116 & 392 & 401.5 \\
\hline 7 & 6.45 & 6.33 & 324 & 268 & 224 & 168 & 24.3 & 24.3 & 111.652 & 20.6 & 16 & 208 & 707 & 532.5 \\
\hline 8 & 6.2 & 6.04 & 316 & 300 & 152 & 128 & 39.852 & 41.796 & 76.632 & 89.404 & 140 & 256 & 609 & 680 \\
\hline 9 & 6.51 & 6.34 & 396 & 520 & 224 & 252 & 41.796 & 65.124 & 100.52 & 147.908 & 104 & 224 & 660 & 1016 \\
\hline 10 & 6.97 & 6.53 & 376 & 348 & 204 & 152 & 41.796 & 47.628 & 61.388 & 82.4 & 152 & 192 & 673 & 532 \\
\hline 11 & 6.41 & 6.25 & 620 & 228 & 376 & 52 & 59.292 & 42.768 & 196.524 & 93.524 & 260 & 132 & 1158 & 428.5 \\
\hline 12 & 7.37 & 7.01 & 244 & 212 & 148 & 108 & 23.328 & 25.272 & 78.28 & 69.216 & 124 & 168 & 848 & 692 \\
\hline 13 & 6.44 & 6.37 & 216 & 372 & 140 & 240 & 18.468 & 32.076 & 50.264 & 117.832 & 100 & 312 & 426 & 522 \\
\hline 14 & 7.01 & 6.74 & 280 & 268 & 136 & 152 & 34.99 & 28.188 & 46.968 & 44.908 & 56 & 76 & 444 & 340.5 \\
\hline 15 & 6.51 & 6.58 & 268 & 332 & 124 & 200 & 34.992 & 32.076 & 65.92 & 66.33 & 76 & 160 & 499 & 601 \\
\hline 16 & 5.96 & 6.28 & 104 & 160 & 68 & 100 & 8.748 & 14.58 & 13.18 & 21.012 & 28 & 32 & 220 & 246 \\
\hline 17 & 6.10 & 6.07 & 200 & 160 & 88 & 116 & 27.216 & 10.692 & 66.33 & 47.38 & 72 & 300 & 455 & 353.5 \\
\hline 18 & 6.75 & 6.92 & 176 & 168 & 92 & 104 & 20.412 & 15.552 & 28.84 & 16.48 & 36 & 40 & 288 & 287.5 \\
\hline 19 & 6.19 & 5.95 & 220 & 240 & 124 & 180 & 23.328 & 14.58 & 53.56 & 65.096 & 76 & 168 & 475 & 546.5 \\
\hline 20 & 7.68 & 7.15 & 180 & 224 & 92 & 152 & 21.384 & 17.496 & 379.04 & 63.86 & 48 & 140 & 315 & 419 \\
\hline
\end{tabular}


Fig. 2 Variation in

concentration of different water quality parameters in groundwater of Dhanbad township, a pH, b Ca hardness, c total hardness, d Mg hardness, e sulphate, $\mathbf{f}$ chloride, and g TDS
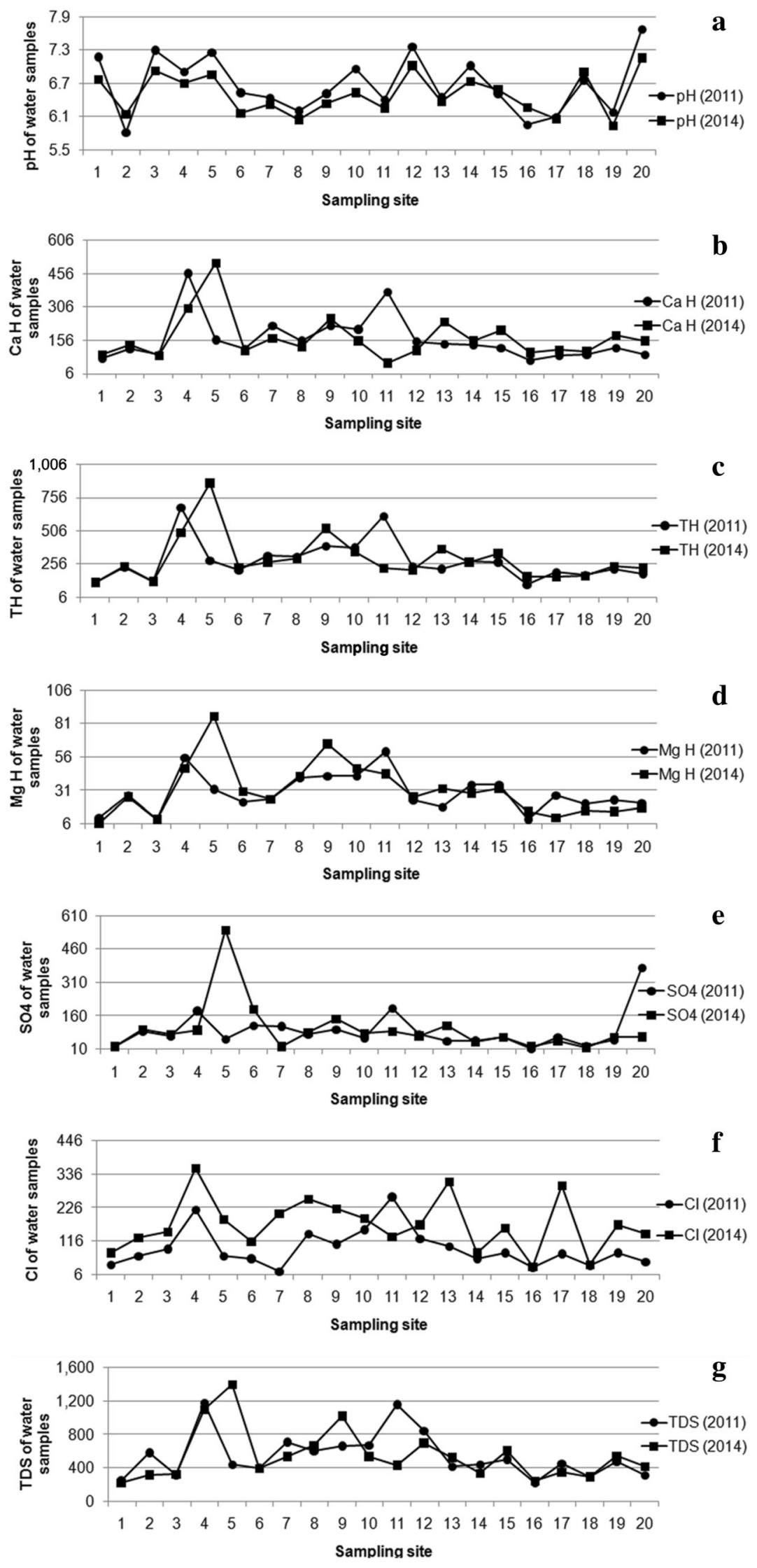
Table 2 Analysis of heavy metals concentration (ppm) in ground water (in mg/l)

\begin{tabular}{|c|c|c|c|c|c|c|c|c|c|c|c|c|c|c|}
\hline \multirow{2}{*}{$\frac{\text { Sampling site }}{1}$} & \multicolumn{2}{|c|}{ Analysis of $\mathrm{Cu}$} & \multicolumn{2}{|c|}{ Analysis of Mn } & \multicolumn{2}{|c|}{ Analysis of $\mathrm{Fe}$} & \multicolumn{2}{|c|}{ Analysis of $\mathrm{Pb}$} & \multicolumn{2}{|c|}{ Analysis of $\mathrm{Cd}$} & \multicolumn{2}{|c|}{ Analysis of $\mathrm{Zn}$} & \multicolumn{2}{|c|}{ Analysis of $\mathrm{Cr}$} \\
\hline & 0.003 & 0.001 & 0.004 & 0.066 & 0.067 & 0.242 & 0.005 & BDL & BDL & BDL & 0.015 & 0.022 & BDL & BDL \\
\hline 2 & 0.004 & 0.002 & 0.250 & 0.009 & 0.024 & 0.056 & 0.003 & $\mathrm{BDL}$ & $\mathrm{BDL}$ & $\mathrm{BDL}$ & 0.096 & 0.071 & BDL & $\mathrm{BDL}$ \\
\hline 3 & 0.004 & 0.002 & 0.036 & 0.016 & 0.093 & 0.052 & 0.049 & 0.009 & $\mathrm{BDL}$ & $\mathrm{BDL}$ & BDL & 0.141 & BDL & $\mathrm{BDL}$ \\
\hline 4 & 0.033 & 0.002 & 0.011 & 0.436 & 0.418 & 0.133 & BDL & BDL & BDL & BDL & 0.224 & 0.148 & 0.004 & 0.004 \\
\hline 5 & 0.005 & 0.004 & 0.035 & 0.073 & 1.399 & 0.063 & 0.003 & 0.002 & BDL & $\mathrm{BDL}$ & 0.172 & 0.195 & BDL & $\mathrm{BDL}$ \\
\hline 6 & 0.002 & 0.001 & 0.374 & 0.441 & 0.438 & 0.081 & BDL & BDL & BDL & BDL & 0.011 & 0.022 & BDL & BDL \\
\hline 7 & 0.011 & 0.005 & 0.111 & 0.152 & 0.385 & 0.208 & 0.001 & 0.001 & BDL & BDL & 0.026 & 0.033 & BDL & BDL \\
\hline 8 & 0.009 & 0.005 & 0.008 & 0.018 & 1.667 & 0.511 & BDL & BDL & BDL & BDL & 0.281 & 0.052 & 0.002 & 0.002 \\
\hline 9 & 0.014 & 0.003 & 0.196 & 0.039 & 1.986 & 0.094 & BDL & BDL & BDL & BDL & 0.019 & 0.009 & BDL & BDL \\
\hline 10 & 0.001 & 0.003 & 0.006 & 0.005 & $\mathrm{BDL}^{*}$ & 0.063 & BDL & BDL & BDL & BDL & 0.038 & 0.027 & BDL & BDL \\
\hline 11 & 0.031 & 0.002 & 1.246 & 0.495 & 0.079 & 0.081 & 0.002 & 0.009 & BDL & BDL & 0.097 & 0.058 & 0.006 & 0.005 \\
\hline 12 & 0.002 & 0.005 & 0.001 & 0.109 & $\mathrm{BDL}^{*}$ & 0.124 & BDL & 0.011 & BDL & BDL & BDL & BDL & 0.001 & 0.001 \\
\hline 13 & 0.006 & 0.003 & 0.029 & 0.019 & 0.165 & 0.057 & BDL & 0.001 & 0.004 & BDL & 0.031 & 0.030 & 0.003 & 0.002 \\
\hline 14 & 0.003 & 0.001 & 0.092 & 0.015 & 0.001 & 0.040 & 0.001 & 0.001 & BDL & BDL & 0.032 & 0.032 & 0.004 & 0.003 \\
\hline 15 & 0.008 & 0.001 & 0.004 & 0.073 & 0.550 & 0.063 & 0.001 & 0.002 & 0.004 & BDL & 0.078 & 0.019 & 0.002 & BDL \\
\hline 16 & 0.006 & 0.002 & 0.009 & 0.349 & 0.689 & 0.276 & 0.001 & 0.005 & BDL & BDL & 0.177 & 0.146 & 0.002 & 0.002 \\
\hline 17 & 0.014 & 0.001 & 0.015 & 0.017 & 2.450 & 0.147 & 0.002 & 0.001 & BDL & BDL & 0.023 & 0.028 & 0.003 & 0.002 \\
\hline 18 & 0.002 & 0.001 & 0.168 & 0.047 & 0.378 & 0.248 & BDL & BDL & BDL & BDL & 0.069 & 0.022 & 0.001 & 0.001 \\
\hline 19 & 0.008 & 0.003 & 0.101 & 0.036 & 0.810 & 0.064 & BDL & BDL & BDL & BDL & 0.469 & 0.091 & 0.002 & 0.002 \\
\hline 20 & 0.004 & 0.008 & 0.008 & 0.002 & 0.123 & 0.031 & 0.001 & 0.001 & BDL & BDL & 0.079 & 0.048 & 0.003 & BDL \\
\hline
\end{tabular}

* Below detection limit

water specification, IS: 10500). Chloride concentration in one sampling point $11(260 \mathrm{mg} / \mathrm{l})$ in 2011 and four sampling point $4,8,13$, and $17(356,256,312$, and $300 \mathrm{mg} / \mathrm{l})$ in 2014 are higher than the desirable limit $(250 \mathrm{mg} / \mathrm{l})$ of Indian drinking water specification. This observation favours decrease in recharge of aquifers and increased mineral content in groundwater in 2014. Eight groundwater samples in 2011 and ten in 2014 have exceeded the desirable limit of $500 \mathrm{mg} / \mathrm{l}$ with respect to TDS value (Table 1). During the investigation period, the highest TDS of $1184 \mathrm{mg} / \mathrm{l}$ in 2011 and $1401 \mathrm{mg} / \mathrm{l}$ in 2014 has been obtained which indicate high dissolved mineral content in groundwater of Dhanbad Township.

The evaluation of concentration of seven heavy metals such as $\mathrm{Cu}, \mathrm{Mn}, \mathrm{Fe}, \mathrm{Pb}, \mathrm{Cd}, \mathrm{Zn}$, and $\mathrm{Cr}$ in the years 2011 and 2014 in groundwater of Dhanbad town is listed in Table 2. The highest concentration of $\mathrm{Cu}, \mathrm{Mn}, \mathrm{Fe}, \mathrm{Pb}, \mathrm{Cd}$, $\mathrm{Zn}$, and $\mathrm{Cr}$ in groundwater in the years 2011 and 2014 has been found $0.033,1.246,2.451,0.049,0.004,0.469,0.006$ and $0.008,0.495,0.511,0.009$, BDL, 0.195, 0.045, respectively (Fig. 3). From the results, it has been observed that concentrations of $\mathrm{Cu}, \mathrm{Pb}, \mathrm{Cd}, \mathrm{Zn}$, and $\mathrm{Cr}$ were well below the permissible limit of Indian drinking water specification (IS: 10500). The concentration of Mn and Fe has been found more than the permissible limit at many places in both the years, but the concentrations have shown a declination trend from 2011 to 2014. In 2011, at seven sampling site $(2,6,7,9,11,18$, and 19), Mn concentration has been more than the permissible limit of $0.1 \mathrm{mg} / \mathrm{l}$, but in 2014, six sampling sites $(4,6,7,11,12$, and 16) have concentration above the permissible limit. Similarly, in 2011 at 11 sampling points $(4,5,6,7,8,9,15,16,17,18$, and 19), Fe concentration has been more than the permissible limit of $0.3 \mathrm{mg} / \mathrm{l}$, and in 2014, only one sampling site 8 has shown higher concentration of $\mathrm{Fe}(0.511 \mathrm{mg} / \mathrm{l})$. The decrease in metal concentration in 2014 as compared to 2011 indicates that less leaching of these metals from ground strata to groundwater has been taken place.

The Heavy Metal Pollution Index (HPI) model (Eqs. 1 and 2) proposed given by (Mohan et al. 1996) has been used for knowing the total quality of groundwater with respect to heavy metals in the years 2011 and 2014:

$\mathrm{HPI}=\frac{\sum_{i=1}^{n} W_{i} Q_{i}}{\sum_{i=1}^{n} W_{i}}$,

where $Q_{i}$ is the sub-index of the $i$ th parameter. $W_{i}$ is the unit weightage of the $i$ th parameter and $n$ is the number of parameters considered.

The sub-index $\left(Q_{i}\right)$ of the parameter is calculated by

$Q i=\sum_{i=1}^{n} \frac{\left\{M_{i}(-) I_{i}\right\}}{\left(S_{i}-I_{i}\right)} \times 100$,

where $M_{i}$ is the monitored value of heavy metal of the $i$ th parameter, $I_{i}$ is the ideal value of the $i$ th parameter, and $S_{i}$ 
Fig. 3 Variation in

concentration of different heavy metals in groundwater of

Dhanbad Township, a Fe, b Mn, c $\mathrm{Cu}, \mathbf{d} \mathrm{Zn}, \mathbf{e} \mathrm{Pb}, \mathbf{f} \mathrm{Cr}$, and $\mathbf{g} \mathrm{Cd}$
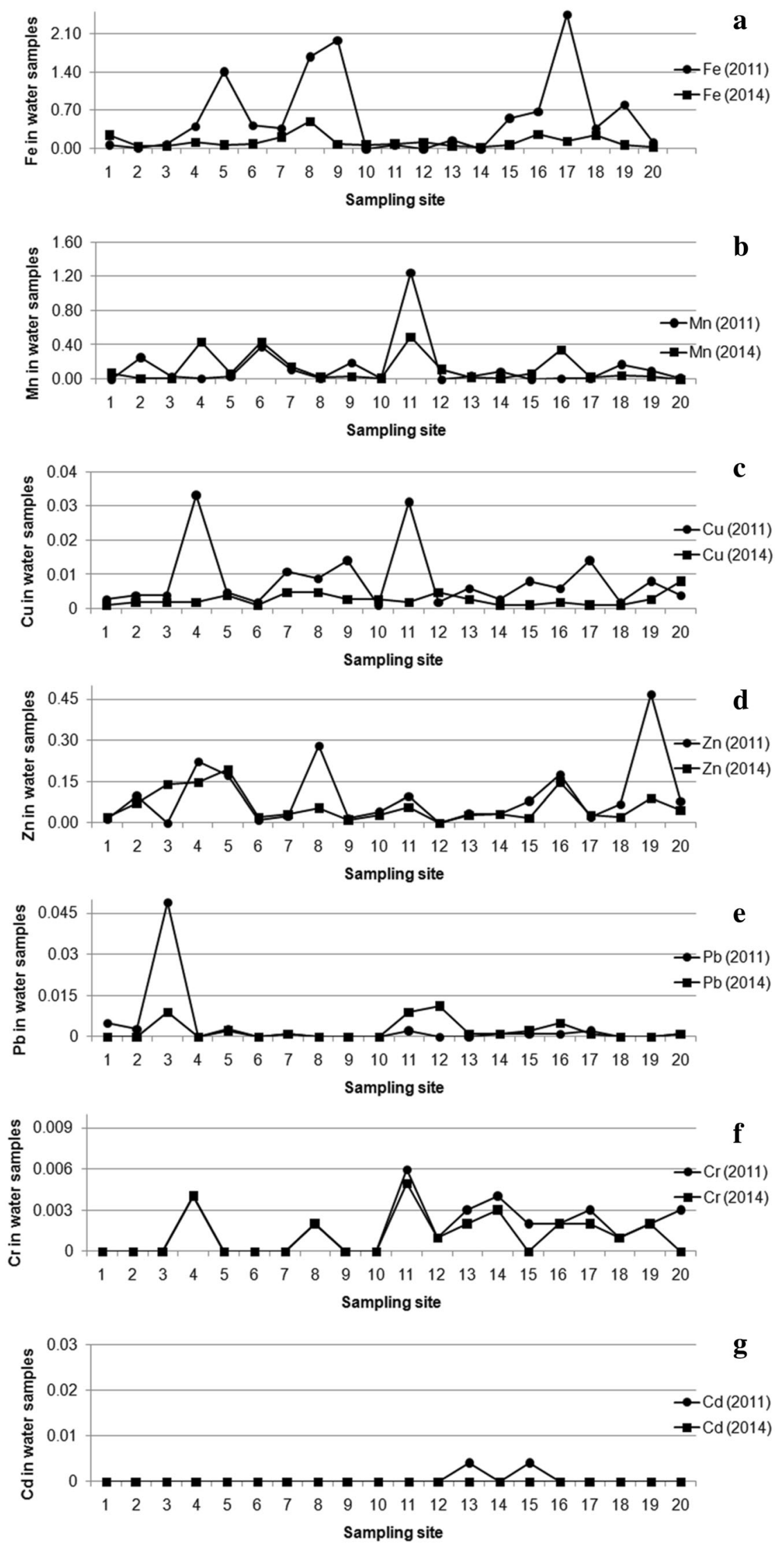
is the standard value of the $i$ th parameter. The sign $(-)$ indicates the numerical difference of the two values, ignoring the algebraic sign.

Since the unit weightage $\left(W_{i}\right)$ of Fe and Mn is very less in HPI calculation of groundwater, these metals contribute very less on HPI value. Heavy metals such as $\mathrm{Pb}, \mathrm{Cd}$, and $\mathrm{Cr}$ have no relaxation in drinking water standard and they have high unit weightage $\left(W_{i}\right)$ value in HPI calculation. Hence, even their very low concentration present in water makes it of poor quality and gives high values in HPI evaluation. The HPI calculation of groundwater quality of Dhanbad Township in the years 2011 and 2014 in the lean period is given in Tables 3 and 4 . The value of HPI calculation in the year 2011 is 4.7640 and its value decreased to 1.4735 in the year 2014 supports the fact that less leaching of these metals from ground strata to groundwater is taking place. Overall, the groundwater of Dhanbad town with respect to heavy metal contamination is not a serious issue and groundwater contamination of the township is not taking place due to severe coal mining activity near the township, though the concentration of few water quality parameters such as total hardness, $\mathrm{Ca}$ hardness, $\mathrm{Mg}$ hardness, chloride, sulphate, and total dissolved solids has increased in 2014 as compared to 2011, which may be due to increased mineral content in groundwater in lean period and decrease in recharge rate of aquifers in 2014. From overall study, it has been seen that different water quality parameters in the year 2014 have not shown any significant change with respect to the year 2011 and there is no significant degradation in the quality of groundwater. In the incoming years, quality of groundwater of Dhanbad Township will not show any drastic change in its quality unless and until any anthropogenic activity will affect it.

\section{Conclusion}

The concentration of various water quality parameters such as total hardness, $\mathrm{Ca}$ hardness, $\mathrm{Mg}$ hardness, chloride, sulphate, and total dissolved solids has been increased in 2014 as compared to 2011 which might be due to increase in mineral content in the lean period and decrease in the recharge of aquifers in 2014. The value of HPI calculation in the year 2011 was 4.7640 and its value decreased to 1.4735 in the year 2014 supports the fact that less leaching of heavy metals from ground strata to groundwater had

Table 3 HPI calculation for groundwater of Dhanbad Town in 2011

\begin{tabular}{|c|c|c|c|c|c|c|}
\hline $\begin{array}{l}\text { Heavy } \\
\text { metal }\end{array}$ & $\begin{array}{l}\text { Mean value } \\
\text { (ppb) } M_{i}\end{array}$ & $\begin{array}{l}\text { Standard permissible } \\
\text { value }(\mathrm{ppb}) S_{i}\end{array}$ & $\begin{array}{l}\text { Highest desirable } \\
\text { value (ppb) } I_{i}\end{array}$ & $\begin{array}{l}\text { Unit weightage } \\
\left(W_{i}\right)\end{array}$ & $\begin{array}{l}\text { Sub-index } \\
\left(Q_{i}\right)\end{array}$ & $W_{i} \times Q_{i}$ \\
\hline $\mathrm{Cu}$ & 8.5 & 1500 & 50 & 0.0006 & 2.8620 & 0.0017 \\
\hline $\mathrm{Mn}$ & 135.2 & 300 & 100 & 0.0033 & 17.6 & 0.0580 \\
\hline $\mathrm{Zn}$ & 96.85 & 15000 & 5000 & 0.00006 & 49.03 & 0.0029 \\
\hline $\mathrm{Pb}$ & 3.45 & 50 & - & 0.02 & 6.9 & 0.138 \\
\hline $\mathrm{Fe}$ & 131.7 & 1000 & 300 & 0.001 & 24.042 & 0.0240 \\
\hline $\mathrm{Cd}$ & 0.4 & 10 & - & 0.1 & 4 & 0.4 \\
\hline $\mathrm{Cr}$ & 1.65 & 50 & - & $\begin{array}{l}0.02 \\
\sum W_{i}=0.14496\end{array}$ & 3.3 & $\begin{array}{l}0.066 \\
\sum W_{i} \times Q_{i}=0.6906\end{array}$ \\
\hline
\end{tabular}

HPI $=4.7640$

Table 4 HPI calculation for groundwater of Dhanbad Town in 2014

\begin{tabular}{|c|c|c|c|c|c|c|}
\hline $\begin{array}{l}\text { Heavy } \\
\text { metal }\end{array}$ & $\begin{array}{l}\text { Mean value } \\
\text { (ppb) } M_{i}\end{array}$ & $\begin{array}{l}\text { Standard permissible } \\
\text { value }(\mathrm{ppb}) S_{i}\end{array}$ & $\begin{array}{l}\text { Highest desirable } \\
\text { value (ppb) } I_{i}\end{array}$ & $\begin{array}{l}\text { Unit weightage } \\
\left(W_{i}\right)\end{array}$ & $\begin{array}{l}\text { Sub-index } \\
\left(Q_{i}\right)\end{array}$ & $W_{i} \times Q_{i}$ \\
\hline $\mathrm{Cu}$ & 2.75 & 1500 & 50 & 0.0006 & 3.258 & 0.0019 \\
\hline $\mathrm{Mn}$ & 120.85 & 300 & 100 & 0.0033 & 10.425 & 0.034 \\
\hline $\mathrm{Zn}$ & 59.70 & 15000 & 5000 & 0.00006 & 49.403 & 0.0029 \\
\hline $\mathrm{Pb}$ & 2.15 & 50 & - & 0.02 & 4.3 & 0.0286 \\
\hline $\mathrm{Fe}$ & 586.1 & 1000 & 300 & 0.001 & 40.857 & 0.0408 \\
\hline $\mathrm{Cd}$ & 0.0 & 10 & - & 0.1 & 0.0 & 0.0 \\
\hline $\mathrm{Cr}$ & 1.2 & 50 & - & $\begin{array}{l}0.02 \\
\sum W_{i}=0.14496\end{array}$ & 2.4 & $\begin{array}{l}0.048 \\
\sum W_{i} \times Q_{i}=0.2136\end{array}$ \\
\hline
\end{tabular}

$\mathrm{HPI}=1.4735$ 
taken place. Overall, the contamination of groundwater of Dhanbad town was not a serious issue and groundwater contamination of the township was not taking place due to severe coal mining activity near the township. Different water quality parameters in the year 2014 did not show any significant change with respect to the year 2011 and there was no significant degradation in the quality of groundwater. On the basis of the study, it was predicted that in the coming years, quality of ground water will not show any drastic change in its quality unless and until any anthropogenic activity will affect it.

Acknowledgements Authors are grateful to Dr. P. K. Singh, Director, CSIR-Central Institute of Mining and Fuel Research, Dhanbad, for continuous encouragement. Authors are also thankful to Dr. Amalendu Sinha, Ex. Director of CSIR-CIMFR, Dhanbad, India for the support during the investigation period. The second author is thankful to DST-INSPIRE for the research fellowship provided to her.

Open Access This article is distributed under the terms of the Creative Commons Attribution 4.0 International License (http:// creativecommons.org/licenses/by/4.0/), which permits unrestricted use, distribution, and reproduction in any medium, provided you give appropriate credit to the original author(s) and the source, provide a link to the Creative Commons license, and indicate if changes were made.

\section{References}

Arnold EG, Lemore SC, Andrew DE (1992) Standard methods for the examination of water and wastewater, 18th edn. American Public Health Association (APHA), Washington, DC

Banks D, Younger PL, Arnesen RT, Iversen ER, Banks SB (1997) Mine water chemistry: the good, the bad and the ugly. Environ Geol 32:157-173. doi:10.1007/s002540050204

Bukowski P, Bromik T, Augustyniak I (2006) Using the DRASTIC system to assess the vulnerability of groundwater to pollution in mined areas of upper Silesian coal basin. Mine Water Environ 25:15-22. doi:10.1007/s10230-006-0104-8

Chabukdhara M, Gupta SK, Kotecha Y, Nema AK (2017) Groundwater quality in Ghaziabad district, Uttar Pradesh, India: multivariate and health risk assessment. Chemosphere 179:167-178. doi:10.1016/j.chemosphere.2017.03.086

Custodio E, Andreu-Rodes JM, Aragon R, Estrela T, Ferrer J, GarciaArostegui JL, Manzano M, Rodriguez-Hernandez L, Sahuquillo A, del Villar A (2016) Groundwater intensive use and mining in south-eastern peninsular Spain: hydrogeological, economic and social aspects. Sci Total Environ 559:302-316. doi:10.1016/j. scitotenv.2016.02.107

Gautam SK, Maharana C, Sharma D, Singh AK, Tripathi JK, Singh SK (2015) Evaluation of groundwater quality in the Chotanagpur plateau region of the Subarnarekha river basin, Jharkhand State, India. Sustain Water Qual Ecol 6:57-74. doi:10.1016/j.swaqe. 2015.06.001

Indian Standard IS: 3025 (2009) Methods of sampling and test (physical and chemical) for water used in industry. Bureau of Indian Standard, New Delhi
Karroum M, Elgettafi M, Elmandour A, Wilske C, Himi M, Casas A (2017) Geochemical processes controlling groundwater quality under semi arid environment: a case study in central Morocco. Sci Total Environ 609:1140. doi:10.1016/j.scitotenv.2017.07.199

Kumari S, Singh AK, Verma AK, Yaduvanshi NPS (2014) Assessment and spatial distribution of groundwater quality in industrial areas of Ghaziabad, India. Environ Monit Assess 186(1):501-514. doi:10.1007/s10661-013-3393-y

Mohan SV, Nithila P, Reddy SJ (1996) Estimation of heavy metal in drinking water and development of heavy metal pollution index. J Environ Sci Health A 31:283. doi:10.1080/ 10934529609376357

Pathak V, Banerjee AK (1992) Mine water pollution studies in Chapha incline, Umaria coalfields, Eastern Madhya Pradesh, India. Mine Water Environ 11:27-36. doi:10.1007/BF02919584

Prasad B, Bose JM (2001) Evaluation of heavy metal pollution index for surface and spring water near lime stone mining area of lower Himalayas. Environ Geol 4:183-188. doi:10.1007/ s002540100380

Prasad B, Jaiprakas KC (1999) Evaluation of heavy metals in ground water near mining area and development of heavy metal pollution index. J Environ Sci Health A 34:91-102. doi:10. 1080/10934529909376825

Prasad B, Kumari S (2008) Heavy metal pollution index of ground water of an abandoned opencast mine filled with fly ash. Mine Water Environ 27:265-267. doi:10.1007/s10230-008-0050-8

Prasad B, Mondal KK (2008) The impact of filling an abandoned open cast mine with fly ash on groundwater quality: a case study. Mine Water Environ 27:40-45. doi:10.1007/s10230-007-0021-5

Prasad B, Sangita K, Tewary BK (2011) Reducing the hardness of mine water using transformed fly ash. Mine Water Environ 30(1):61-66. doi:10.1007/s10230-010-0130-4

Prasad B, Kumari P, Bano S, Kumari S (2014) Groundwater quality evaluation near mining area and development of heavy metal pollution index. Water Sci Technol 4:11-17. doi:10.1080/ 10934529909376825

Saravanakumar K, Kumar RR (2011) Analysis of water quality parameters of groundwater near Ambattur industrial area, Tamil Nadu, India. Indian J Sci Technol 4(5):660-662. doi:10.17485/ ijst/2011/v4i5/30071

Selvakumar S, Ramkumar K, Chandrasekar N, Magesh NS, Kaliraj S (2017) Groundwater quality and its suitability for drinking and irrigational use in the Southern Tiruchirappalli district, Tamil Nadu, India. Appl Water Sci 7(1):411-420. doi:10.1007/s13201014-0256-9

Singh G (1988) Impact of coal mining on mine water quality. Int $\mathbf{J}$ Mine Water 7:49-59

Srinivas Y, Aghil TB, Oliver DH, Nair CN, Chandrasekar N (2017) Hydrochemical characteristics and quality assessment of groundwater along the Manavalakurichi coast, Tamil Nadu, India. Appl Water Sci 7(3):1429-1438. doi:10.1007/s13201-015-0325-8

Verma DK, Bhunia GS, Shit PK, Kumar S, Mandal J, Padbhushan R (2017) Spatial variability of groundwater quality of Sabour block, Bhagalpur district (Bihar, India). Appl Water Sci 7(4):1997-2008. doi:10.1007/s13201-016-0380-9

\section{Publisher's Note}

Springer Nature remains neutral with regard to jurisdictional claims in published maps and institutional affiliations. 